\title{
Pemberdayaan Perempuan/Ibu Tunggal Melalui Pelatihan Pembuatan Produk Industri Rumah Tangga Halal dan Sehat Sebagai Usaha Peningkatan Self Efikasi Diri Dalam Berwirausaha
}

\author{
Noor Fitri ${ }^{1}$, Rr. Indahria Sulistyarini ${ }^{2}$, Yuni Windarti ${ }^{3}$ \\ ${ }^{1}$ Department of Chemistry, Universitas Islam Indonesia, Yogyakarta, Indonesia \\ ${ }^{2}$ Department of Psychology, Universitas Islam Indonesia, Yogyakarta, Indonesia \\ ${ }^{3}$ Department of Communication, Universitas Islam Indonesia, Yogyakarta, Indonesia \\ *Corresponding Email: noor.fitri@uii.ac.id
}

\begin{abstract}
ABSTRAK
Pengabdian ini fokus kepada pemberdayaan perempuan/ibu tunggal melalu pelatihan pembuatann produk industri rumah tangga yang halal dan sehat sebagai usaha peningkatan self efikasi diri dalam berwira usaha. Produk industri rumah tangga yang dikembangkan adalah sosis dan keju. Program pemberdayaan yang dilakukan meliputi (1) Support Group Therapy dan Motivasi Edukasi Perempuan dalam Ikhtiar dan Tawakkal; (2) Pangan Halal Sehat dan Komposisi Kimiawi dalam Makanan; (3) pembuatan sosis; dan (4) pembuatan keju. Peserta pelatihan adalah perempuan/Ibu Tunggal maupun Ibu rumah tangga yang menjadi tulang punggung keluarga. Mitra kegiatan ini adalah Yayasan Rumpun Nurani, yaitu sebuah lembaga nirlaba yang berfokus pada pengembangan, penguatan Sumber Daya Manusia melalui bidang pendidikan, sosial, dakwah dan ekonomi. Sinergi Pengabdi UII dan mitra Yayasan Rumpun Nurani bertujuan untuk pemberdayaan perempuan/Ibu Tunggal menjadi ibu tangguh, peningkatan keterampilan usaha, serta penyediaan sosis dan keju halal, sehat dan bergisi bagi umat. Program ini dapat direkomendasikan menjadi program wilayah pemerintah Yogyakarta maupun nasional dalam pemberdayaan ibu tunggal menjadi ibu yang tangguh dan produktif dalam rangka penguatan ketahanan keluarga bangsa Indonesia.
\end{abstract}

Kata kunci : komunitas perempuan/ibu tunggal, produk natural halal sehat, self efikasi

\begin{abstract}
This community service focuses on empowering women / single mothers through training in the manufacture of halal and healthy home industry products as an effort to increase self-efficacy in entrepreneurship. Home industry products developed are sausages and cheese. The empowerment programs include (1) Support Group Therapy and Women's Education Motivation in Efforts and Tawakkal; (2) Healthy Halal Food and Chemical composition of food; (3) production of sausage; and (4) production of cheese. The training participants are women / single mothers and housewives who are the backbone of the family. The partner of this activity is the Rumpun Nurani Foundation, a non-profit organization that focuses on developing, strengthening Human Resources through education, social, dakwah and economic fields. The synergy of researcher from UII and the Rumpun Nurani Foundation aims to empower women / single mothers to become resilient mothers, improve business skills, and provide halal healthy sausages and cheese for the people. This program can be recommended as a program of Yogyakarta Government or national program in empowering single mothers to become strong and productive mothers.
\end{abstract}

Keywords: community of women / single mothers, healthy halal natural products, self-efficacy 


\section{PENDAHULUAN}

Indonesia darurat sosis dan keju. Dua produk olahan ini beredar luas di pasaran dan sangat digemari tua muda, anak-anak hingga dewasa. Sosis - produk olahan daging dan keju - produk olahan susu mempunyai nilai gizi tinggi. Produk olahan ini digunakan sebagai sumber karbohidrat dan protein. Namun kenyataannya, banyak sosis maupun keju di pasaran yang memiliki komposisi gizi jauh di bawah standar yang telah ditetapkan dan mengandung zat aditif sintetik [1].

Hal tersebut ditunjukkan pada pemakaian jumlah komposisi utama (daging dan susu) kurang atau penggunaan bahan tidak sesuai komposisi standar produk olahan. Komponen utama sosis terdiri dari daging, lemak, dan air, sedangkan keju komposisi utamanya adalah susu sapi/kambing [2]. Namun sosis yang beredar dipasaran berasal dari campuran pati. Bahkan jajanan sosis beredar di sekolah diproduksi tanpa daging sama sekali dan berwarna merah (sosis abal-abal) dijual dengan harga sangat murah Rp 500/tusuk. Ada pula sosis dengan kandungan lemak jenuh sangat tinggi karena menggunakan tetelan tinggi lemak. Belum lagi terkait isu halal dari casing sosis yang menggunakan usus babi [3]. Selain itu, penambahan bahan tambahan seperti garam, fosfat, pengawet (biasanya nitrit/nitrat), pewarna, asam askorbat, isolat protein dan penggunakan zat tambahan kimia lain yang menyebabkan potensi penyakit [4].

Senada dengan produk olahan sosis, keju olahan ini terbuat dari sedikit susu dan banyak minyak nabati, pati jagung, pewarna dan perasa sintetik [5]. Padahal menurut FDA, organisasi yang mengatur bahan makanan telah menetapkan komposisi keju proses yakni 1:1 antara keju natural dan bahan kimia. Namun sayangnya, aturan ini tidak berjalan sesuai ketetapan, banyak produsen keju proses tak mengindahkan hal ini. Bahkan keju olahan dengan merk terkenal di Indonesia hanya mengandung $16 \%$ keju natural. Penambahan berbagai bahan kimia juga menyebabkan keju olahan mampu bertahan lama dalam suhu ruang. Sementara keju natural harus selalu disimpan pada suhu rendah [6].

Pandangann orang tua bahwa keju terbuat dari susu yang merupakan sumber protein dan beranggapan memberi anaknya roti keju agar kebutuhan gizi terpenuhi adalah jauh api dari panggangan [7]. Sungguh suatu kenyataan berbeda dengan harapan. Tak heran menurut data Riset Kesehatan Dasar/Riskesdas 2013 menyatakan sekitar 37\% (hampir 9 Juta) anak mengalami gizi buruk. Tak pelak, Indonesia sebagai negara dengan prevalensi stunting kelima terbesar di dunia [8].

Disisi lain, popularitas produk olahan baik sosis maupun keju merupakan peluang bagi tumbuhnya produk sejenis yang lebih memperhatikan kualitas kesehatan - tanpa MSG, tanpa Pengawet maupun tanpa pewarna buatan. Data survei independen yang dilakukan oleh perusahaan swasta menunjukkan bahwa konsumsi sosis oleh masyarakat Indonesia tumbuh rata-rata 4,46\% per tahun [9]. Terdapat potensi pasar yang besar terhadap produk kesehatan seperti susu dan 
turunannya, sebanyak 90 juta jiwa pelanggan baru (new consumer) pada tahun 2030 mendatang [10].

Hal inilah yang mendasari dilakukannya kegiatan pelatihan produk rumahan pada komunitas perempuan khususnya ibu tunggal (single parent) [10]. Sebagai wujud partisipasi masyarakat (terutama perempuan) pada produk olahan susu dan daging industri rumah tangga. Banyak yang belum mengerti cara pembuatan sosis dan keju. Keju dianggap sebagai makanan yang mewah dan mahal, sehingga menimbulkan kesan bahwa pembuatan keju sangat sulit. Sesungguhnya keju dapat diproduksi sebagai industri rumah tangga (homemade).

Fokus kegiatan pengabdian ini adalah pemberdayaan perempuan terutama ibu tunggal untuk peningkatan self efikasi diri dalam berwirausaha. Perempuan merupakan motor penggerak perekonomian handal dalam keluarga, terutama kaum perempuan yang berperan sebagai tulang punggung keluarga. Kegiatan pelatihan ini bertujuan untuk meningkatkan keterampilan/skill perempuan dalam konteks pemberdayaan masyarakat guna peningkatan kualitas hidup [11].

Pelatihan dalam kegiatan pengabdian ini dibungkus dalam pendidikan informal berupa pendidikan kewirausahaan. Tujuan pelatihan ini adalah pendidikan motivasi, pendidikan pengetahuan, pendidikan keahlian (skill), dan pengembangan kemampuan (ability). Menurut Sumarno (2013), berdasarkan keempat tujuan, dimungkinkan terjadinya suatu kemandirian, realisasi gagasan, optimalisasi manfaat, dan pengembangan potensi diri yang berkelanjuta (Priyanto, 2009) [12].

Mitra yang dilibatkan dalam program pengabdian masyarakat adalah mitra yang bergerak dibidang ekonomi produktif, yaitu Yayasan Rumpun Nurani Yogyakarta. Yayasan Rumpun Nurani adalah sebuah lembaga nirlaba yang berfokus pada pengembangan, penguatan sumber daya manusia melalui bidang pendidikan, sosial, dakwah dan ekonomi. Salah satu ikhtiar kemandirian bidang ekonomi adalah dibentuknya NunShop, wadah penyedia makanan dari ummat untuk ummat, dari komunitas dan untuk komunitas. Adapun makanan yang dijual oleh NunShop merupakan produk natural dan sehat (tidak mengandung pengawet, pewarna buatan dan penyedap rasa berlebihan). Delapan puluh persen (80\%) komposisi produk harus terdiri dari komponen natural dan alami. Saat ini, mitra mengalami kesulitan dalam pengembangan produksi makan sehat alami berskala kecil dan rumahan (homemade), yaitu sosis dan keju. Seperti diketahui bahwa produk sosis dan keju sangat marak dan digemari dari seluruh kalangan. Di sisi lain, produk yang beredar di pasaran sangat memprihatinkan dari segi komposisi bahannya. Hal tersebut menjadi permasalahan prioritas yang disepakati untuk diselesaikan, yaitu : (1) Kesulitan penyediaan bahan baku yang berkualitas dan halal (slongsongan dan bumbu khas sosis); (2) Rendahnya kapasitas produksi pembuatan sosis berskala rumahan/homemade; (3) Belum diterimanya produk secara 
meluas; (4) Rendahnya pengetahuan dan kepedulian masyarakat terhadap makanan alami dan halal; (5) Rendahnya motivasi, pengetahuan dan keterampilan membuat makanan sehat berasal dari rumah.

Solusi dari permasalahan tersebut berupa bantuan pengembangan produk makanan natural berskala rumahan/homemade, penyuluhan dan pelatihan pembuatan keju pada penyedia makanan utama di rumah, yaitu ibu-ibu (terutama ibu tunggal dan calon ibu) yang berada dalam naungan Yayasan Rumpun Nurani. Harapan dari kegiatan tersebut adalah seiring meningkatnya produktivitas makanan natural (sosis dan keju), meningkat pula kesadaran masyarakat tentang produk natural yang halal dan sehat. Dengan demikian konsumsi sosis dan keju bukan olahan pabrik pun mengalami peningkatan. Potensi ini berpeluang pada geliat ekonomi umat yang mendorong kemandirian ekonomi komunitas ibu (khususnya ibu tunggal) maupun lembaga mitra.

\section{METODE}

\section{a. Penyuluhan dan pelatihan}

Pengabdian Masyarakat dilakukan dengan metode pemaparan materi (penyuluhan), dan praktek (hands on). Adapun penyuluhan dilakukan dengan materi terkait Support Grup Therapy (khusus bagi ibu tunggal dalam incomplete family), Pangan Halal Sehat, Motivasi Edukasi Perempuan dalam Ikhtiar dan Tawakal, dan Komposisi Kimiawi dalam Makanan. Sedangkan pelatihan pembuatan produk rumahan yaitu sosis dan keju dilakukan dengan penyuluhan dan sesi tanya jawab dilanjut dengan praktek membuat sosis dan keju.

Penyuluhan dilakukan oleh pemateri mumpuni berlatar belakang psikologi, kimia, komunikasi dan pegiat olahan natural. Pelatihan produk olahan susu dan daging dilakukan dengan pemberikan kesempatan pada peserta praktek langsung dengan didampingi oleh pemateri. Bahan dan peralatan yang digunakan diupayakan sesederhana mungkin dan mudah ditemui agar peserta tak menemui kesulitan jika akan mengaplikasikan di lingkungan masing-masing. Hanya beberapa alat seperti termometer susu dan cetakan keju yang mungkin tidak atau belum dimiliki oleh peserta pelatihan. Bahan pembuatan sosis dan keju disiapkan oleh tim mulai dari susu, bakteri keju, daging ayam, slongsongan sosis dan bumbu yang diperlukan. Setelah pelatihan peserta diperbolehkan membawa hasil belajar dan diberikan bahan pembuatan sosis dan keju (kit sosis dan keju) secara gratis. Hal ini dilakukan untuk mempermudah proses pengulangan materi yang telah diberikan pada pelatihan.

\section{b. Waktu dan Tempat Pengabdian}

Pengabdian masyarakat ini dilaksanakan pada bulan April-Juli 2019 di Panasan Donoharjo, Ngaglik, Sleman 


\section{c. Subyek Pengabdian}

Peserta pengabdian ini adalah ibu ibu yang berusia 25-50 tahun. Karena keterbatasan pendanaan, sebelum dilakukan kegiatan pengabdian berupa penyuluhan dan pelatihan, peserta diseleksi terlebih dahulu. Peserta yang mendaftar ada 50 orang, kemudian diseleksi 20 orang ibu yang merupakan ibu tunggal (diutamakan), ibu yang berperan sebagai penopang utama ekonomi keluarga dan ibu yang memiliki hobi memasak.

\section{HASIL DAN PEMBAHASAN}

a. Support Group Therapy dan Motivasi Edukasi Perempuan dalam Ikhtiar dan Tawakkal

Workshop motivasi dan edukasi untuk perempuan dalam ihktiar dan tawakkal diperuntukkan khusus hanya untuk ibu tunggal. Ibu tunggal memiliki kondisi yang rentan baik secara psikis maupun ekonomi, sehingga diperlukan penanganan khusus. Termasuk memotivasi diri para ibu tunggal agar mampu berdaya optimal untuk diri, keluarga maupun fungsi sosialnya. Ibu tunggal yang memiliki kemampuan/kecakapan dalam melakukan aktifitas akan memunculkan keyakinan pada dirinya untuk berusaha. Berdasarkan pernyataan tersebut maka penelitian yang sekaligus sebagai sarana pengabdian masyarakat bertujuan untuk membentuk efikasi diri pada ibu tunggal sehingga ibu tunggal dapat lebih berdaya dan mandiri terutama dalam pemenuhan kebutuhan hidupnya.

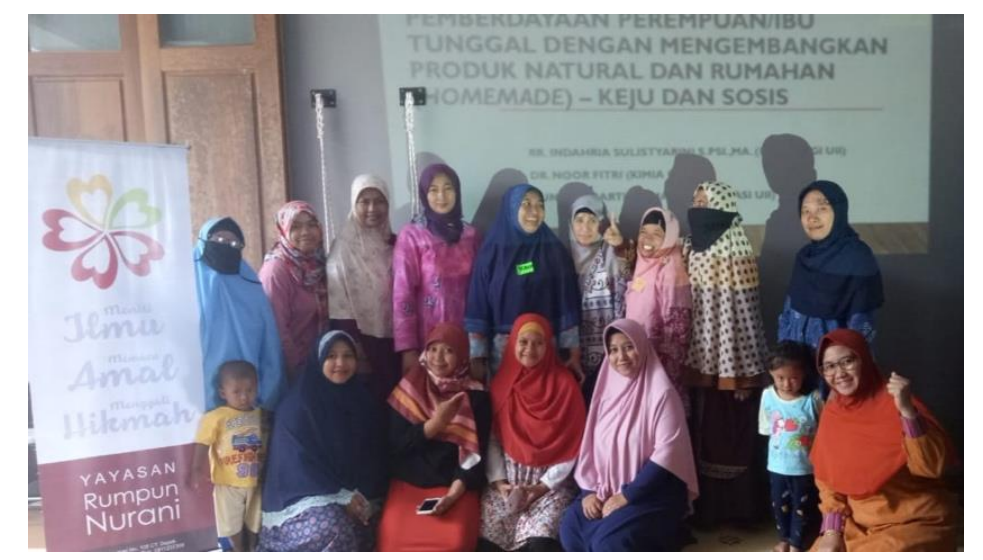

Gambar 1. Kegiatan workshop Pemberdayaan Ibu Tunggal

\section{b. Pangan Halal Sehat dan Komposisi Kimiawi dalam Makanan}

Pelatihan pemberdayaan perempuan/ibu tunggal yang dilakukan dalam pengabdian ini adalah pelatihan pembuatan produk rumah yang halal dan sehat, dalam hal ini pembuatan sosis dan keju. Sebagaimana diketahui sosis dan keju yang beredar di pasaran $85 \%$ berasal dari pabrik/perusahaan besar dan umumnya menggunakan bahan pengawet dan bahan aditif kimia lainnya [13]. Sosis dan 
keju olahan industri rumah tangga masih sangat sedikit, sehingga peluang bisnis industri rumah ini sangat menjanjikan. Selain itu, masyarakat masa kini mulai paham arti kesehatan dan makanan sehat, dan mencari makanan olahan yang sehat dan halal. Salah satu materi pendukung dalam pembuatan produk industri rumah tangga seperti sosis dan keju adalah materi tentang pangan halal dan sehat serta ilmu tentang komposisi kimiawi dalam makanan. Materi pangan halal sehat dan komposisi kimiawi dalam makanan disampaikan oleh ibu Dr. Noor Fitri. Materi penyuluhan ini meliputi defenisi pangan halal beserta dasar hukum syar'i halal yang tertera dalam Al quran; pangan sehat yang bergisi, serta komposisi kimiawi dalam makanan. Kode halal dalam label makanan kemasan juga disampaikan dalam pelatihan ini. Makanan halal adalah makanan yang dapat dikonsumsi umat muslim yang diperbolehkan dalam syariat Islam. Allah menyampaikan petunjuk tentang makanan halal dan syarat-syarat makanan dalam Al Quran sebanyak 109 kali [14]. Menurut buku petunjuk teknis yang diterbitkan oleh Departemen Agama Islam, makanan halal adalah barang yang dimaksudkan untuk dimakan dan diminum oleh manusia dan serta bahan yang digunakannya adalah halal [15]. Allah telah mengatur dengan jelas apa yang dapat dikonsumsi oleh manusia berdasarkan manfaatnya dan mengharamkan segala sesuatu yang mendatangkan mudhorot atau akibat buruk bagi yang memakannya.

Allah berfirman dalam surat $\mathrm{Al}$ maidah ayat 88 bahwa Allah telah memerintahkan pada manusia untuk makan makanan halal saja [14, Al Quran, Surah Al Maidah ayat 88]. .

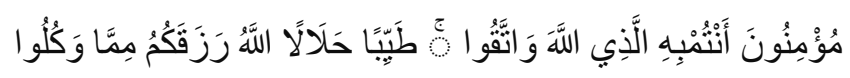

"Dan makanlah makanan yang halal lagi baik dari apa yang telah Allah rezekikan kepadamu dan bertaqwalah kepada Allah yang kamu beriman kepada Nya."

Pada dasarnya semua makanan dan minuman adalah mubah atau dibolehkan untuk dikonsumsi, kecuali yang diharamkan oleh Allah dalam Al-Quran. Sehingga sangat banyak jenis makanan dan minuman yang dapat dikonsumsi dibandingkan yang diharamkan. Dalam Al Qur'an surah Al Baqarah ayat 173, Allah menjelaskan makanan dan minuman yang diharamkan untuk dikonsumsi oleh umat muslim. Makanan yang haram tersebut adalah bangkai, darah, daging babi, dan binatang yang ketika disembelih tidak menyebut nama Allah [14, Al Quran surah Al Baqarah ayat 173].

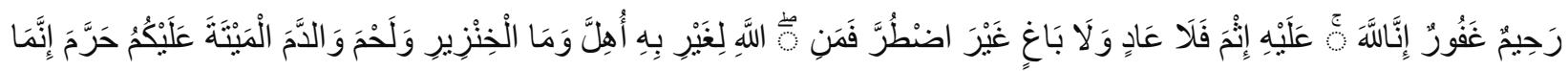
"Sesungguhnya Allah hanya mengharamkan bagimu bangkai, darah, daging babi, dan binatang yang (ketika disembelih) disebut (nama) selain Allah. Tetapi barangsiapa dalam keadaan terpaksa 
(memakannya) sedang dia tidak menginginkannya dan tidak (pula) melampaui batas, maka tidak ada dosa baginya. Sesungguhnya Allah Maha Pengampun lagi Maha Penyayang”( QS Al Baqarah, 173)

Makanan halal dalam Islam harus memenuhi syarat halal dalam hal: (1) halal zatnya; (2) halal cara memperolehnya; (3) halal cara memprosesnya; (4) serta halal cara menyajikan, mengantarkan serta menyimpannya [16].

Halal zatnya berarti sumber alami makanan tersebut adalah halal, bukan yang diharamkan oleh Allah seperti yang disampaikan dalam Al Quran. Halal cara memperoleh maksudnya untuk membeli atau mendapatkan bahan makanan tersebut dengan cara yang benar, bukan dengan uang haram atau proses yang haram seperti mencuri. Halal cara prosesnya berarti makanan diproses dengan cara halal menggunakan perangkat masak yang halal, tidak bercampur dengan perangkat memasak makanan yang haram seperti babi. Syarat ke empat adalah halal cara menyajika, mengantarkan serta menyimpannya. Tidak disimpan bersamaan dengan makanan yang haram seperti makanan yang terbuat dari babi. atau disajikan menggunakan piring emas. Empat syarat tersebut harus dipenuhi dalam menyiapkan makanan halal. Masyarakat awam masih sangat sedikit yang mengetahui empat syarat makanan halal ini.

Pengetahuan tentang konsep halal ini sangat penting, sehingga dalam membuat sosis dan keju, umat Islam tidak menggunakan bahan tersebut. Sebagai contoh, masih ada sebagian masyarakat di Yogyakarta yang mengkonsumsi saren. Saren dalam darah yang dipadatkan. Darah direbus sehingga mengental dan padat. Saren ini karena berasal dari darah, sehingga haram untuk dikonsumsi. Prinsip-prinsip Islam bahwa segala sesuatu yang diperintahkan kepada manusia adalah untuk kebaikan manusia sendiri dan segala sesuatu yang dilarang/diharamkan juga untuk kebaikan manusia juga. Makanan yang diharamkan tentu membawa keburukan/tidak sehat untuk dikonsumsi. Sebagaimana diketahui dalam darah banyak sekali bibit penyakit, sehingga tidak baik untuk dikonsumsi[17].

Edukasi makanan halal dan sehat ini juga dapat meningkatkan pemahaman tentang prinsip Islam dan menambah keyakinan dalam menyiapkan makanan halal dan sehat bagi umat Islam. Dalam edukasi ini juga disampaikan jika pengusaha muslim/muslimah memproduksi makanan industri rumah tangga yang halal dan sehat dalam rangka menyediakan makanan halal dan sehat bagi umat sesuai perintah Allah dalam Al qur'an, maka insyaAllah akan bernilai pahala di sisi Allah swt. Sehingga orientasi peserta workshop tidak hanya materi duniawi mendapatkan penghasilan namun juga berorientasi untuk bekal akhirat. 
Setelah prinsip halal untuk makanan, materi selanjutnya adalah pembahasan tentang makanan sehat, aditif makanan yang alami dan sintetik, serta komposisi kimiawi senyawa dalam makanan. Pemahaman tentang semua bahan makanan adalah senyawa kimia juga disampaikan. Karena masyarakat selalu menganggap bahan kimia adalah senyawa yang berbahaya. Semua makanan mengandung senyawa kimia, yang perlu diperhatikan adalah senyawa kimia yang terkandung dalam makanan apakah bahan kimia alami atau sintetik. Sebagai contoh pewarna makanan yang digunakan apakah berasal dari bahan alami atau pewarna sintetik. Selongsong sosis yang digunakan, apakah berasal dari bahan alami atau plastik/ bahan kimia sintetik [18]. Selongsong sosis yang alami berasal dari alginat tumbuhan maupun kolagen sapi, domba, kambing atau babi. Sedangkan selongsong sosis yang sintetik terbuat dari selulosa, kolagen, dan plastik (poliamida, polipropilena, polietilena). Tentu saja selongsong sosis yang baik adalah yang alami dan edible (dapat dikonsumsi). Akan tetapi umat Islam harus mengetahui apakah selongsong tersebut berasal dari bahan alami yang halal atau haram. Edukasi ini sangat bermanfaat bagi peserta pelatihan, sehingga dapat lebih teliti dalam menyiapkan sosis yang halal dan sehat.

Selain itu, pemaparan tentang pengolahan makanan yang baik juga disampaikan, sehingga nilai gisi tetap terjaga dan meminimalkan hilangnya nilai gisi karena proses masak yang keliru. Edukasi tentang makanan halal sehat serta komposisi kimia ini mendapat respon yang sangat positif dari semua peserta pelatihan.

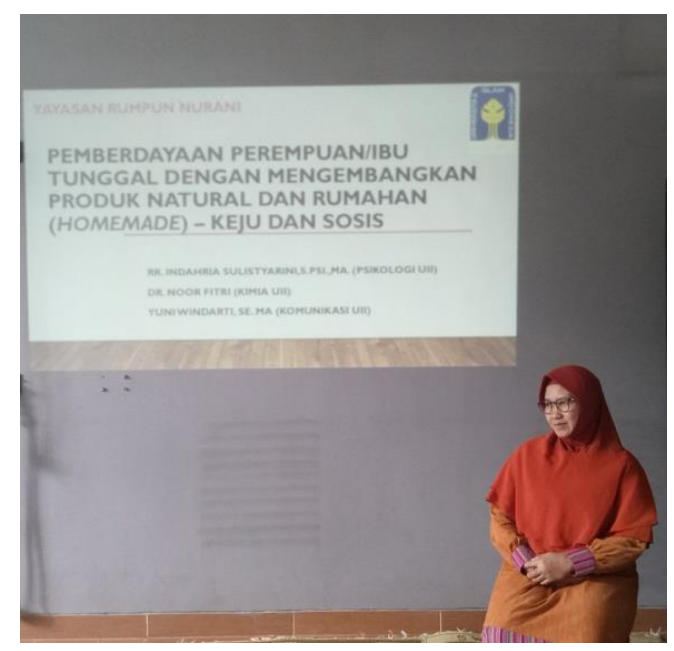

Gambar 2. Edukasi makanan halal sehat pada pelatihan pemberdayaan ibu tunggal

\section{c. Pembuatan Sosis}

Pelatihan pembuatan sosis diawali dengan materi tentang sejarah pengawetan daging. Asal muasal sosis dan 3 macam kategori sosis yang dikonsumsi masyarakat yaitu; (1) sosis segar yang biasanya dijual dalam pendingin dan tahan hanya beberapa hari, (2) sosis asap dimana masa konsumsinya lebih panjang dibanding sosis segar (2-3bulan) disimpan dalam chiller, dan (3) sosis 
fermentasi yang masa konsumsinya bertahun-tahun di luar kulkas. Biasanya penampakannya kering. Ada ribuan macam sosis karena dikombinasikan dengan bermacam daging (sapi, ayam, babi, domba dll), bermacam-macam proses (rebus, asap, kukus), macam-macam casing/slongsongan, macam-macam bentuk dan bermacam rasa. Misal sosis bratwust dari Jerman, sosis Thailand dengan bumbu khas serai dan lengkuasnya, termasuk Indonesia mungkin dengan kari opor atau rendangnya (inovasi sosis). Pengenalan tentang beragam bahan baku casing/slongsongan dan pentingnya penggunaan slongsongan halal menjadi diskusi menarik.
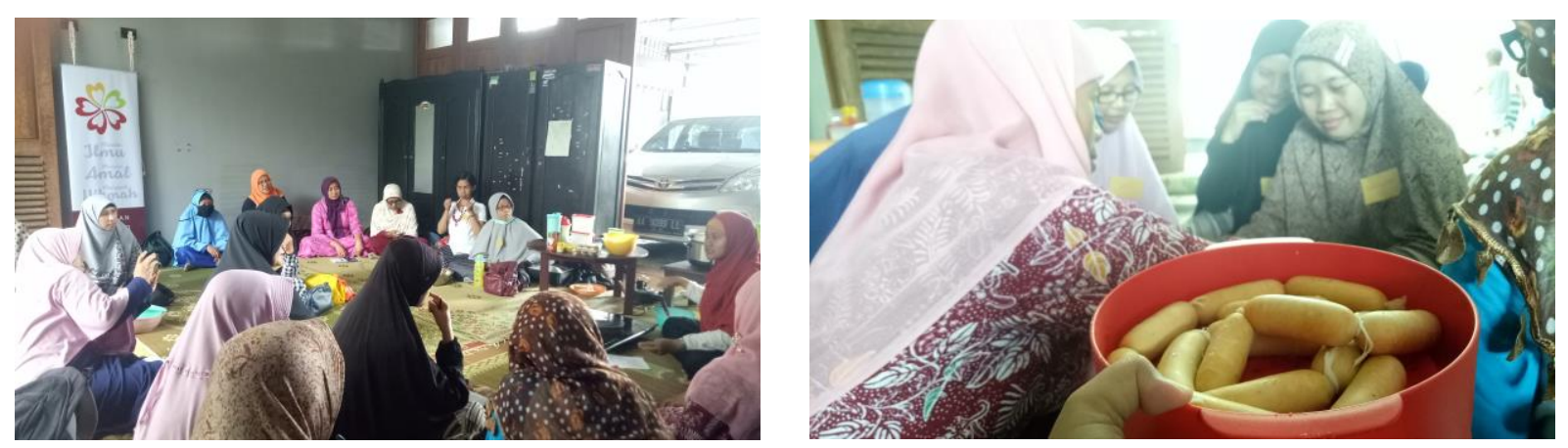

Gambar 3. Pelatihan Pembuatan Sosis halal natural sehat

Pada pelatihan kali ini, digunakan bahan daging ayam, bumbu dasar dari bawang bombay, bawang merah dan bawang putih dengan penambahan bumbu rempah ala bratwust. Sosis yang diajarkan merupakan sosis asap dengan teknis rebus dan kukus. Adapun proses pembuatan sangat sederhana, digunakan daging giling yang mudah ditemui disupermaket maupun pasar tradisional, semua bumbu dimasukan termasuk tepung pati ( 2 sendok makan atau sesuai selera), susu dan telur diaduk menjadi rata. Setelah adonan rata dimasukkan dalam plastik piping yang juga mudah didapatkan di toko roti. Lalu adonan dimasukkan dalam slongsongan, diikat sesuai selera lalu direbus/dikukus. Sosis dapat segera dikonsumsi. Mudah dan tanpa bahan pengawet dan kimia berbahaya.

Setelah pelatihan peserta diberi kit cukup untuk praktek lagi di rumah. Kit berisi slongsongan sosis dan bumbu rempah bratwust. Para ibu kemudian berpraktik membuat sosis di rumah dan melaporkan hasil dalam grup WhatsApp. Beberapa muncul terkait keberhasilan dan kegagalan membuat sosis. Namun para ibu tak menyerah. Ada yang bahkan berhasil mengajarkan kembali proses pembuatan sosis homemade ini dilingkungan tetangga sekitar mereka tinggal. Beberapa berhasil membuat sosis untuk konsumi keluarga. Ada yang berinovasi membuat sosis menggunakan bahan non daging yaitu jamur. Yang paling menarik, ada ibu yang berhasil membuat sosis dan kemudian layak dijual bekerjasama dengan yayasan. Sosis ini diberi nama Nura Sosis, berbahan dasar daging ayam dijual Rp 25.000-30.000 per 200-250 gram berat sosis. 


\section{d. Pembuatan Keju}

Pelatihan pembuatan keju dimulai dengan pemaparan tentang sejarah keju dan prinsip pembuatan keju. Keju yang diajarkan kali ini adalah keju havarti atau keju lembaran yang belum cukup familiar dimasyarakat. Sebelumnya peserta pelatihan diinformasikan tentang proses pasteurisasi susu. Adapun tahapan pembuatan keju havarti adalah memanaskan suhu susu pasteurisasi hingga kondisi dimana bakteri MM100 dapat berkembang dengan baik. Lalu ditambahan Rennet untuk proses koagulasi. Setelah itu dilakukan proses pemisahan tahu susu (curd) yang dipadatkan dalam cetakan sesuai keinginan dan dilakukan penggaraman, Tahap selanjutnya adalah proses fermentasi dan pengepressan selama 8 jam lalu proses pengeraman keju dalam chiller selama kurang lebih 1 bulan.

Pada awalnya peserta cukup antusias mengikuti kegiatan. Setelah pelatihan, peserta diberikan kit keju yang berisi bakteri MM100 untuk jenis keju Havarti, dan Rennet (telah ada sertifikasi halal) untuk dibawa pulang. Namun selanjutnya, tak ada ibu yang mencoba membuat sendiri keju di rumah. Pelbagai alasan muncul diantaranya para ibu mengeluh sulitnya mendapatkan susu pasteurisasi murah dan berkualitas dilingkungan tempat mereka tinggal, ketersediaan alat berupa termometer susu maupun cetakan keju menjadi hambatan. Tidak segera dapat dikonsumsinya keju (harus menunggu 1 bulan) turut membuat para ibu kurang bersemangat dalam mencoba membuat keju sendiri dirumah. Hal ini merupakan tantangan ke depan dalam upaya mengedukasi masyarakat terkait proses pembuatan keju rumahan.
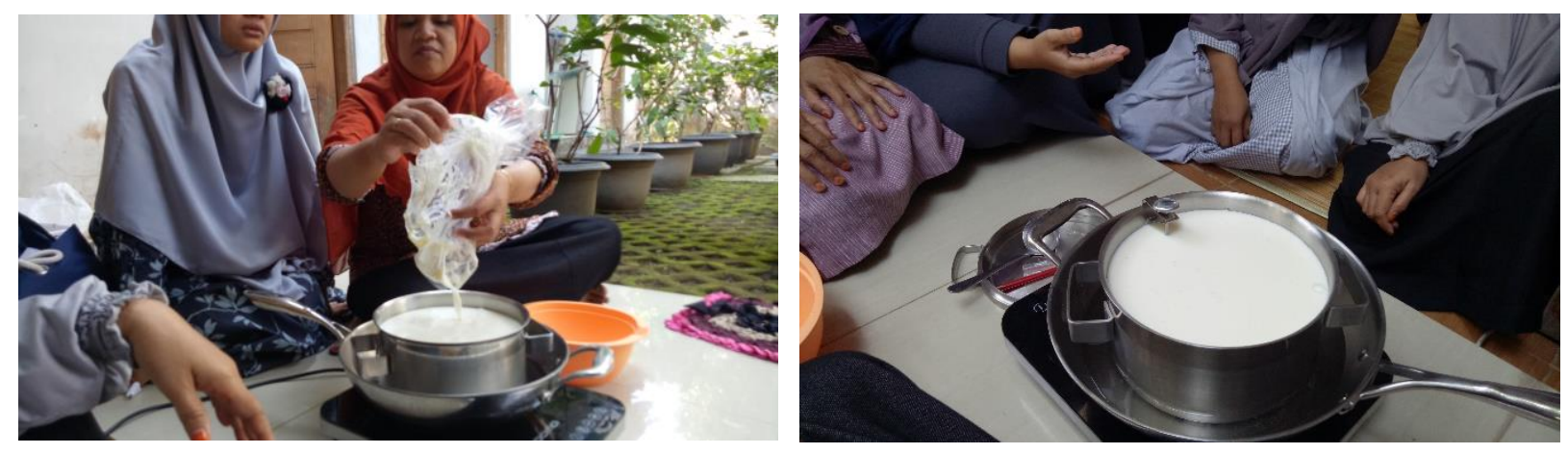

Gambar 4. Pelatihan Pembuatan Keju halal sehat

\section{SIMPULAN}

Kegiatan pengabdian yang dilaksanakan meliputi penyuluhan materi psikologi, kajian kimia pada makanan, serta pelatihan pembuatan produk alami halal sehat keju dan sosis. Peserta tidak hanya diberi keterampilan tentang pengolahan keju dan sosis namun juga edukasi terkait motivasi self efikasi serta pengetahuan pangan halal sehat dan komposisi kimia makanan. Kegiatan pelatihan ini menyebabkan partisipasi perempuan cukup tinggi sehingga dilakukan proses seleksi diawal kegiatan. Bahkan setelah kegiatan penyuluhan dan pelatihan berakhir, masih terdapat ibu- 
ibu yang menanyakan kegiatan pelatihan sosis dan keju, hal ini pertanda baik dan merupakan apresiasi baik dari masyarakat terkait pengolahan susu dan olahan daging yang berkualitas. Semoga kedepan masyarakat lebih perduli pada pengolahan makanan yang lebih sehat dan bergizi.

Kegiatan pengabdian berhasil mengedukasi masyarakat terutama perempuan/ibu tunggal terkait pengolahan natural susu dan keju yang sehat tidak menggunakan pengawet, MSG dan bahan kimia berbahaya lainya. Masyarakat teredukasi tentang pentingnya mengolah makanan yang berasal dari rumah agar pemenuhan gizi keluarga terpenuhi dan bisa menambah penghasilan keluarga. Kedepannya kegiatan serupa perlu digalakkan, dengan komunitas yang lebih luas dan perluasan program misal pendanaan ibu tunggal agar mandiri secara keuangan. Kegiatan ini dapat direkomendasi menjadi salah satu program pemberdayaan perempuan tangguh oleh pemerintah provinsi Yogyakarta maupun skala nasional dalam rangka penguatan ketahanan keluarga bangsa Indonesia.

\section{UCAPAN TERIMA KASIH}

Pengabdi menghaturkan terima kasih kepada DPPM UII yang telah memberikan dana hibah pengabdian sesuai dengan surat perjanjian pelaksanaan pengabdian masyarakat No: 11/Dir/DPPM/80/PM Unggulan/IV/2019. Pengabdi juga mengucapkan terima kasih kepada mitra pengabdian, Yayasan Rumpun Nurani atas kerjasamanya sehingga kegiatan ini dapat berjalan dengan lancar dan sukses.

\section{DAFTAR PUSTAKA}

[1]Made A. Bahaya Laten Sepotong Sosis. 2008. Departemen Teknologi Pangan Dan Gizi IPB. [Internet]. [diunduh pada 2020 Jan 14]. Tersedia pada: https://nasional.kompas.com/read/2008/10/31/11473267/bahaya.laten.sepotong.sosis?page=all

[2]Herlina, Darmawan I, Rusdianto, AS. 2015. Penggunaan Tepung Glukomanan Umbi Gembili (Dioscorea esculenta L.) sebagai Bahan Tambahan Makanan pada Pengolahan Sosis Daging Ayam. Jurnal Agroteknologi. 09(02)

[3]Satryorik. 2016. Waspada Bahaya Sosis Murah. [Internet]. [diunduh pada 2020 Jan 14]. Tersedia pada: https://www.kaskus.co.id/thread/5846321954c07a33088b456c/waspadabahaya-sosis-murah/

[4] Sujarwanta RO, Suryanto E, Setiyono, Supadmo, Rusman. 2016. Kualitas Sosis Daging Sapi yang Difortifikasi dengan Minyak Ikan KOD dan Minyak Jagung dan Diproses Menggunakan Metode Pemasakan yang Berbeda. Buletin Peternakan. 40 (1): 48-57 
[5]Syamsu K dan Elsahida K. 2018. Pembuatan Keju Nabati dari Kedelai Menggunakan Bakteri Asam Laktat yang Diisolasi dari Dadih. Jurnal Teknologi Industri Pertanian. 28 (2):154-161

[6]Ratnani R. D. 2009. Bahaya Bahan Tambahan Makanan bagi Kesehatan. Momentum. 5(1): $16-22$

[7]Setya D. Kenali! Ini Bedanya Keju Natural dan Keju Buatan Pabrik. 2019. [Internet]. [diunduh pada 2020 Jan 14]. Tersedia pada: https://food.detik.com/info-kuliner/d-4473824/kenali-inibedanya-keju-natural-dan-keju-buatan-pabrik

[8]Tim Nasional Percepatan Penanggunlangan Kemiskinan. 2017. 100 Kabupaten/Kota Prioritas untuk Intervensi Anak Kerdil (Stunting). TNP2K. Jakarta.

[9]Dewi N. 2007. Kajian Pembuatan Keju Olahan. Jurnal Ilmu dan Teknologi Hasil Ternak. 2(1): $10-14$

[10] Afrilia AM. 2017. Penggunaan New Media di Kalangan Ibu Muda sebagai Media Parenting Masa Kini. Jurnal Komunikasi dan Kajian Media (1)1: 31-42

[11] Sari U. 2019. Eksistensi Perkembangan Perekonomian Perempuan di Era Digitalisasi. An Nisa' Jurnal Studi Gender dan Anak. 12(1): 596-609

[12]Ife J dan Tesoriero F. 2014. Community Development : Alternatif Pengembangan yang terjadi di Era Globalisasi. Pustaka Pelajar. Yogyakarta.

[13]Tiara P. 2017. AWAS! Ada Kandungan Bahan Kimia Berbahaya dalam Makaroni \& Keju Instan. [Internet]. [diunduh pada 15 Jan 2020]. Tersedia pada: https://lifestyle.okezone.com/read/2017/07/17/481/1738239/awas-ada-kandungan-bahankimia-berbahaya-dalam-makaroni-keju-instan

[14] Al Qur'an

[15]Departemen Agama. 2003. Petunjuk Teknis Pedoman Sistem Produksi Halal

[16] Mohammad A.M. 2010. GM Crops: The Socio-Economic Impacts. International Workshop for Islamic Scholars on Agribiotechnology: Shariah Compliance. Penang, Malaysia.

[17]Lady Y. 2016. Bahaya Mengonsumsi Darah. [Internet]. [diunduh pada 15 Jan 2020]. Tersedia pada: https://bimasislam.kemenag.go.id/post/opini/bahaya-mengonsumsi--darah

[18] European Patent Office. 2002. A heat shrinkable polyamide sausage casing with a polyolefin core layer. 